\title{
Kāhui Ako and the collaborative turn in education: Emergent evidence and leadership implications
}

Annelies Kamp

University of Canterbury, New Zealand

Internationally, in contexts of escalating globalisation, collaboration has increasingly been taken up as a social policy tool. Education has not been exempt from that uptake. In Aotearoa, this is most clearly evidenced in the implementation of Kāhui Ako / Communities of Learning. In this paper, I detail the 'why' of this global shift towards collaborative initiatives, engage with available research as to the limits and possibilities of their successful implementation, and consider the implications of collaboration for leadership. I then draw on theory to advance some practice priorities for realising the potential of such policy initiatives.

Keywords: Wicked problems, collaboration, policy, leadership

\section{Introduction}

Joined-up government is an 'umbrella' term that captures a range of policy initiatives focused on networking, collaboration and partnership in social policy discourse. The term 'joined-up' government is often associated with approaches implemented by the Labour government led by Prime Minister Tony Blair in the United Kingdom from May, 1997 and sustained by subsequent Labour governments (Moore \& Rutherford, 2012). However, the imperative for collaboration in social policy making and practice has been taken up more widely: there is now a "global ubiquity of partnership and collaboration as a policy trend" (Higham \& Yeomans, 2010, p. 382), including in Aotearoa New Zealand (Aotearoa).

Education policy has not been exempt from this shift in social policy more broadly. Since 2013, education policy in Aotearoa has overtly focused on cross-sector collaboration, most centrally through the implementation of Kāhui Ako | Communities of Learning as part of the National government policy on Investing in Educational Success (IES). Kāhui Ako are voluntary collaborations of early childhood, school, kura and post-compulsory education providers who work together to address the number one challenge for the education system in Aotearoa: achieving equity and excellence for ākonga (www.ero.govt.nz). Kāhui Ako attract substantial Vote Education funding which is used to release staff to work collaboratively; there are now over 610,000 children and young people in 1,761 schools working within Kāhui Ako structures. The intervention logic suggests that on-the-grounds change will be evident in first, shared accountability and collective responsibility for students; second, "deliberate" collaboration; third, building and sharing teaching and leadership expertise; fourth, new career pathways for "good" teachers and "outstanding" principals; fifth, evidence-driven action; and sixth, productive partnerships with families, iwi, employers, and the community 
(Ministry of Education, 2018, p. 5). While Kāhui Ako are voluntary, schools and their staffs are effectively incentivised (Charteris \& Smardon, 2018) to engage through the provision of additional resourcing for staff release and the enticement of new career opportunities for principals and teachers (Ministry of Education, 2016).

However, international research, and early evaluations of Kāhui Ako (Ministry of Education, 2017) suggest that such policy initiatives often fail to realise their anticipated benefits. This research literature argues that, in practice, collaboration is a complex, and contested, endeavour. Thrupp's (2018) overview of the implementation of IES illustrates the ways in which critical engagement with policy - particularly where the policy is framed around issues of social justice - has been essential to such success as can be attributed to Kāhui Ako: "It was those who opposed the policy on principled grounds and those who 'entered the tent' on principled grounds who contributed to the improvement of the IES policy" (p. 141). In contrast to what has been argued to be "persistently optimistic policy rhetoric," research has highlighted the difficulties and limitations of partnership (Higham \& Yeomans, 2010, p. 384). This has led to interest in understanding how joined-up approaches are implemented, and the implications of implementation processes for mediating the suggested potential of collaboration to resolve the pressing policy concerns at which they are addressed. My own research suggests that the failure of collaborative initiatives in education to realise all that is anticipated for them reflects a failure of various parts of the education system to follow through on the implications of such policy initiatives, most particularly in regard to accountability mechanisms both within, and beyond, government (Kamp, 2013, 2017). I also argue that there are problems in how we visualise collaboration. It is often imagined as a 'jointhe-dots approach' where existing organisations and institutions are better connected. Clearly, this could bring greater efficiency to the existing education system. However, if greater efficiency of current practice is not the aim, if what is required is some form of systemic change to support new ways of working in solving what appear to be intractable problems of equity, then a different kind of collaboration - one that is more organic and emergent - is required. This, in turn, has implications for how we might think about leadership, and about capacity-building initiatives.

In this review, first I present an overview of the global rationale for the collaborative policy agenda, and its manifestation in Aotearoa. Second, I review empirical research on 'what works' in educational collaboration, where its limitations lie, and what might be done to overcome those limitations. In this I engage with more long-standing developments in the United Kingdom. Third, drawing on insights from contemporary social theory, I consider how the benefits of collaboration might best be achieved in the light of policy reform in Aotearoa. The review closes with leadership for collaboration, and makes suggestions for further development in this regard.

\section{Wicked problems and collaborative solutions}

In the developed West, the latter decades of the twentieth century witnessed a shift in social policy discourse. In a context of globalisation and the advent of so-called 'wicked problems' (Rittel \& Webber, 1973) there was increasing acceptance that effective policy development, and implementation, would require cooperative efforts involving both government, and those who were the subjects of government policy - providers and citizens. 
Horst Rittel was the principal initiator of the argument around 'wicked problems', an argument that would go on to become the subject of the most highly cited paper ever published in Policy Sciences (Crowley \& Head, 2017). A design theorist at the University of California Berkeley, Rittel originally introduced the notion of wicked problems in a seminar in 1967 to refer to:

that class of social system problems which are ill-formulated, where the information is confusing, where there are many clients and decision-makers with conflicting values, and where the ramifications in the whole system are thoroughly confusing. (Churchman, 1967, p. B141)

In a context of social dissent in the United States, Rittel and Webber rejected the idea of a rational systematic approach to planning. As Crowley and Head (2017, p. 541) detail, Rittel and Webber were, in their 1973 paper, presenting an argument that:

Social problems could no longer be addressed by assuming, as science does, that they are 'tame' or 'benign', or definable, separable, and solvable, and thus able to be characterised, analysed and planned for by adopting a rational systems perspective. Wicked problems, which include "nearly all public policy issues" (1973, p. 160), are indeed the opposite. They are 'ill-defined' and 'malignant'. They cannot be 'solved', but are reliant instead upon "elusive political judgment for resolution ... over and over again." (p. 160)

This argument moved beyond systems theory with its study of abstract organisation, to a more localised study of diverse "systemic networks" that were "interacting, open" and "interconnected" (Churchman, 1979, cited in Crowley \& Head, 2017, p. 541). In the first instance, this movement towards diversity had its roots in the recognition of a shift from a unitary 'American way of life' to an increasingly pluralist perspective of "numerous ways of life that are also American" (Churchman, 1979, cited in Crowley \& Head, 2017, p. 541). For Rittel and Webber, whereas 'tame problems' could be clearly defined and always lent themselves to clearly defined policy solutions - often empirically grounded on the basis of evidence, precedent, logic and controlled implementation - this is not the case for problems that are wicked. And, in the context of a rapidly changing world, these social policy problems were increasingly evident.

While humans have travelled and engaged with actors elsewhere in the world for centuries, since the latter decades of the $20^{\text {th }}$ century, particularly as a result of the rapid expansion of information and communication technologies, the pace of globalisation has escalated rapidly (Giddens, 2002). To a greater or lesser degree, depending on where we might live, humans have witnessed rapid change: growing diversity in our communities as a result of increasing mobility, changed familial structures, a global shift to neo-vocationalism, and markets (particularly for international students) in education, increased consumerism, burgeoning technology and so on. Education is an excellent example of a policy space that has become a far more complex endeavour in this more interconnected world. Young people remain at school for longer periods of time, the curriculum is broader and is subject to challenge as to whose knowledge gets privileged, assessment is more complex, the student body is more diverse and transient, the 'stakes' of educational achievement are greater, and pedagogy is reshaped by information and communications technology. Accordingly, policy decisions and policy implementation are both more contested, and more complex; this context demands the effort of multiple actors that each possess some capability to act; it 
involves dependency on others to imagine and develop appropriate policy and to convert it into action (Balloch \& Taylor, 2001; Kickert, Klijn, \& Koppenjan, 1997). While Rittel and Webber never wrote a proposed "constructive companion piece" on solution-making in this context (Catron, 1981), they did advocate for transparent political argumentation as "the key and perhaps the only method of taming wicked problems" (Rith \& Dubberly, 2007, p. 73).

\section{Collaboration and governance}

Connectedness, and harnessing a dispersed capacity to act, has implications for government. Accordingly, in Western democracies at least, we have seen a shift from 'big' government to diverse forms of 'governance' (Denters \& Rose, 2005; Kjaer, 2003). The policy for Kāhui Ako was developed under a National government and its process of implementation shows that genesis. Thrupp (2018) describes how the policy was first announced by the then Prime Minister to business leaders and was greeted with scepticism by many education stakeholders, not least for its high level of prescription around the focus of any collaboration. While collaborative initiatives were already in place in jurisdictions other than Aotearoa, we are at the leading edge in that there has been no example of a "country-wide system of communities" (Education Review Office, 2017). Notwithstanding a change of government and great variation in the impact to date of Kāhui Ako on outcomes, and equity of outcomes across the country, the policy has sustained. The potential for a stronger impulse in the collaborative agenda has since been reinforced with the Education Conversations that occurred across 2019 under a Labour-led government. This could be read as government being increasingly collaborative in policy development, yet continuing to govern 'from a distance' through maintaining various accountability mechanisms of the kind that have become familiar to educators in neoliberal Aotearoa. However, the commitment to "develop and improve the Kāhui Ako model, through less prescriptive settings" as part of the decisions resulting from the Education Conversations is encouraging (Ministry of Education, 2019, p. 34).

A collaborative agenda is pragmatic: it moves government away from top-down planning and dictated programmes while avoiding "market-mediated anarchy" (Jessop, 1998, p. 32). It is an agenda that, in its current form within existing measures of accountability and governance, aligns with the so-called 'third way politics' that were evident in the United Kingdom and that have ebbed and flowed in popularity throughout the twentieth century (Giddens, 1998). Yet, it also moves us closer to the 'fourth way' (Hargreaves \& Shirley, 2012): an approach that is argued to bring change about through democracy and professionalism instead of bureaucracy and/or market. According to Andy Hargreaves and Dennis Shirley, a fourth way approach to change is about inspiration, innovation, responsibility and sustainability. It is inherently joined up, and looks to change relations between government and the community; it functions by gaining insight into and focusing on 'what works' at the local level, by developing an equal and interactive partnership process of capacity building and collaboration, and sustains it by nurturing optimal conditions so that what works locally can flourish, thereby seeding innovations in other contexts. This vision echoes that articulated for Kāhui Ako which, according to the Education Review Office, included a "culture of collective responsibility" where leaders have a "critical role in establishing a compelling collective vision and setting priority goals and targets that represent the perspectives and aspirations of all community participants" (Education Review Office, 2017, p. 7). 
Despite this global interest and theorisation, collaborative approaches - both within education policy and in social policy more broadly - have been suggested to be "always just beyond reach" of governments; while the benefits are extolled, the costs of collaboration tend to be underestimated (Tett, 2005, p. 2). In my research in Australia (Kamp, 2013), and in the United Kingdom (Geddes, 2003; Higham \& Yeomans, 2010), collaborative initiatives have been shown to encounter other parts of the education system in ways that make practice a testing and complex endeavour. This complexity is often invisible in official policy documents and guidelines, and existing competitive impulses, organisational arrangements and forms of accountability often remain unchanged, and unchallenged, despite the policy discourse.

In Aotearoa, a cursory review of the literature from 2000 illustrates the presence of myriad impulses for collaboration. For example, researchers have argued for enhanced collaboration in supporting inclusive and equitable education for students with additional educational needs (Kearney, Mentis, \& Holley-Boen, 2017), in building capacity for research in, and on, early childhood initial teacher education (Nuttall, 2012), in attempts to strengthen initial teacher education policy making (Alison \& Aikin, 2013) and, particularly, in critiques of the unintended consequences and increasing competition that had resulted from Aotearoa's implementation of self-managing schools (Wylie, 2012). ${ }^{1}$ The policy shift towards collaboration in education as mobilised through Kāhui Ako has been argued to be a "'tightloose-tighter' mode of governance with a social justice rationale provided for the tighter reforms" (Charteris \& Smardon, 2018, p. 31) .

\section{Examining the evidence on collaboration: What works?}

In their short discussion of dynamics within Kāhui Ako, Phil Ramsey and Jenny Poskitt (2019) noted the need for different approaches to leadership to overcome the tensions and dilemmas encountered by education leaders in Aotearoa. Both those in positional roles, and those who exert leadership from other standpoints, have for the past three decades worked within autonomous school settings and now must grapple with cross-school leadership and its implications. They argue that Kāhui Ako leadership, while still being fundamentally relational (Eacott, 2015), demands a contingency approach that is highly attuned to context(s). Yet, leadership itself is reframed through discourses evident in policy interventions such as Kāhui Ako. As argued by Charteris and Smardon (2018, p. 31), agency in the context of this, or any policy initiative appears in "the interplay of discursive, social and material influences that shape, and are in turn, shaped by school leaders."

In their research, Charteris and Smardon invited all principals from New Zealand primary and secondary schools to take part in an online survey on professional learning; they then selected 38 principals for semi-structured interviews where the implementation of Kāhui Ako was probed. Their analysis demonstrates a tension in that a policy initiative that is premised on shared expertise to enhance innovation and responsiveness is experienced by some as stifling given the "mandates and conditions" (Charteris \& Smardon, 2018, p. 33),

1 This shift to school autonomy in how outcomes for all students can be lifted is not unique to Aotearoa New Zealand, having become a central precept of OECD policy. However, New Zealand is recognised as one of the most autonomous systems in the OECD, along with the Republic of Ireland, and the Netherlands (OECD, 2015).

2 Given the limits of the paper, I have not engaged with survey research undertaken by the Ministry on Kāhui Ako. For the interested reader, this is available on the Education Counts website (educationcounts.govt.nz). 
presumably including the requirement to focus on negotiated and agreed achievement challenges and reporting requirements. One of their respondents suggests "It's sort of a communal collaborative process with the business model put on top of it" (p. 34). In the process of formalising what were at times existing collaborations, and subjecting them to the accountability requirements that come with the provision of financial support, there is the risk that first-order business - the moral purpose of schools - becomes hostage to the secondorder business of accountability. According to McCarthy, Miller, and Skidmore (2004), this reflects a situation where - given the interconnected complexity of collaborative work accountability and reporting processes can actually be progressively amplified. In the context of New Public Management of which Aotearoa, Australia and the United Kingdom were exemplars (O'Flynn, 2007), schools were, and - at the time of writing - continue to be, individually and in particular ways, replete with performativity, quality assurance, targets, league tables and inspection systems (Kirkpatrick, Ackroyd, \& Walker, 2005). Thus the acquisition of performative information, and the requirement for its use in enhancing and proving evident-based practice across multiple sites, can consume so much energy it "drastically" reduces the energy available for core business associated with the work of schools and other education providers (Elliott, 1996, p. 15).

Kāhui Ako are learning the how of collaboration at the same time as they seek to enhance student outcomes by way of collaboration. For some Kāhui Ako, there is a discomfort in the associated unknowns:

It seems like [the Ministry] are wanting to do something but we just don't quite know what it is that they're wanting to do. It kind of makes you feel like they know the way out of the maze but we are stuck in the middle of it. ... And we are meant to be leading and innovating and collaborating but nobody is to get a newer map to get out. (Charteris \& Smardon, 2018, p. 33)

This quote highlights the complexity of implementing innovations that require educators, and ministerial staff, to actively experiment within a world that is dominated by 'what we usually do' and the existing 'map'. Where some in Kāhui Ako will identify opportunity in the absence of clear guidelines as to how to get 'out of the maze', others can be undone by uncertainty. Kāhui Ako are designed to work in the spaces between schools and kura, early childhood and tertiary education providers and other agencies working for and with ākonga; each of these entities is, in itself, an assemblage of discursive, material, social and political actors. Each entity will hold within it diverse world views, will have a professed culture and multiple subcultures, will work to meet a range of stakeholder expectations and accountabilities, and so on. Hence, within any collaborative agenda an essential recognition must focus on learningin-practice and, particularly, the learning that happens at the boundaries of diverse communities (Wenger, 2000). This process of learning at the boundaries is often private, almost imperceptible; that it cannot be quantified does not mean that it is not occurring. Yet invisibility brings risk of the initiative losing momentum or failing to demonstrate success in the ways that can be accepted by government. Research on system improvement initiatives focused on student achievement has shown that the extent of involvement is a predictor of student achievement gain (Datnow, 2005), and lower levels of involvement tend to be found in schools that have lower student achievement (Kidron \& Darwin, 2007). For Datnow, this potentially reflects that teachers in these schools are focused on the immediate priority of preparing students to achieve in assessment, rather than engaging in the longer term strategic work of collaboration and learning for system change. 
As Rittel and Webber identified in their seminal paper from 1973, this learning at the boundary where communities of practice, organisations, policy documents and individuals come into contact with an imperative to change practice can, and often must, demand transparent, and often political, argumentation. My own research into the collaborative turn in education in the State of Victoria in Australia illustrated this dynamic. Here, the agenda was to ensure all parts of the State, organised around combinations of Local Government Areas, would be provided with incentivised networks (initially in the post-compulsory sector and, subsequently, wider) of education and other community organisations. As is the case in Aotearoa, these networks were introduced into contexts where, at times, organic collaborations focused on innovation were already evident. In Victoria, the initial call to action was based on evidence generated by the Ministerial Inquiry into Postcompulsory Education and Training Pathways (Kirby, 2000). As part of the State Government response, 31 Local Learning and Employment Networks (LLEN) would draw education, community and government together, innovating to enhance provision and support for Victorian students in transition from school to work. The LLEN research showed that this work was necessarily confrontational. It was work that, according to a LLEN Committee Member, required the ability to "think a long way ahead and think strategically and not be concerned about people cackling out there and understand that if there wasn't cackling there' $d$ be nothing there, it would be a dead beast, a dead parrot" (Kamp, 2006, p. 123). This echoes Thrupp's (2018) observation of the importance of what might be called oppositional dialogue around the policy itself.

Greany (2017) notes that in England, prior to 2000 there was no evidence of one model of collaboration that would secure improved student outcomes. A systemic approach began in England in the London Challenge which, from 2004, saw principals (and their staff) from schools that were deemed to be London's most successful working to co-design innovations with 70 schools deemed to be most in need of improvement (Ainscow, 2015). Aspects of the Challenge included support for leadership and teaching and learning, as well as capacity building to enable data-informed decisions; while a significant amount of funding (GBP80m over the eight years of the Challenge) was involved, many schools received very small amounts. While the achievements in London schools could not be attributed to the Challenge alone, respondents did note that "a sense of collegiality and collective responsibility replaced the fragmentation and isolation of the past" (Baars et al., 2014, p. 40). However, respondents noted the end of the Challenge in 2011, the potential of its legacy and the realisation that the "afterglow' of London Challenge (sic)] would not last forever" (Baars et al., 2014, p. 43), a point to which I will return.

Here, I want to focus on one particular initiative from the United Kingdom that sheds light on 'what works.' Around the same time as the London Challenge, Primary Strategy Learning Networks (PSLN) were initiated in England as an imposed and highly-prescriptive model of collaboration for groups of five to eight primary schools focused on raising standards in literacy and numeracy. PSLN were initially allocated funding (GBP 17,000 per network); a target was set, and achieved, for 1,500 networks to be established. The benefits of this initiative were identified to be sharing of resources, and the professional support experienced within what was, in effect, a community of practice: "I think, in essence, the idea of actually reaching out, opening up the school and opening ourselves to new ideas and new possibilities has probably turned out to be the most beneficial aspect of the whole process" (Moore \& Rutherford, 2012, p. 74). The research argued that structures and time were required for success (Moore \& Rutherford, 2012, p. 73). Structures here referred both to the structure of 
the collaboration itself and to the structure of the broader system within which collaboration would occur. Here, the authors note the tension in applying 'structure' to the collaboration: "the organic nature of a network can be supported and enhanced by systems and structures that are adaptable to change" (p. 74). This research suggests that the imposed, incentivised approach to collaboration was "not viewed by most of the ... respondents as excessively demanding, controlling or inhibiting" (Moore \& Rutherford, 2012, p. 74, my emphasis). The PSLN initiative is insightful in that it took the form of collaboration around a particular achievement challenge: enhancing àkonga learning and an improvement in measures of literacy and numeracy. Yet, while the perceived benefits of collaboration were noted by participants in reference to their own experience, and while the structure was adaptable enough to not feel constrictive, there was little evidence of change in classroom practices and improvements in learning opportunities, and limited evidence at the point of evaluation of impact on standards, or pupil outcomes (Moore \& Rutherford, 2012).

Chapman and Hadfield (2010, p. 222) reviewed the formation and operation of a range of education collaborations in England. Their study focused on local government officials advisors, policy makers, managers - who work in relationship with central government and/or local communities to lead and administer a 'partnership culture.' They noted that "paradoxes and dilemmas" are a reflection of the tension within top-down mandates for bottom-up innovation. In what remains of the paper, I want to offer some theoretical provocations on how we might work better within these paradoxes and tensions to achieve the aspirations that have been established for collaborative policy initiatives such as Kāhui Ako.

\section{Theoretical insights}

In the earlier work that I have cited in this paper, I have alluded to the ways that the collaborative policy agenda in education aligns well with contemporary social theory and, in particular, the intellectual concerns of Actor-Network Theory (ANT). Actor-network theorists, such as myself, are concerned with ensuring all actors - "objects, subjects, human beings, machines, animals, 'nature', ideas, organisations, inequalities, scale and sizes, and geographical arrangements" (Law, 2009, p. 141) are taken into consideration when we consider how something 'works'. In the case of the collaborative policy agenda, it is an approach to reading the world that makes sure it speaks about all such entities and considers how they, collectively, make us act. Thus, in considering 'network', the emphasis is not on the structure of the collective, but on the 'work' the collective is encouraged to do, on the basis of the entities which are part of the collective (Latour, 2004). If we do not read closely, using ethnographic approaches that bring all actors - both human and non-human - into our considerations (see Kamp, 2019 for a methodological overview), we will not know what is making us act as we do, what is perhaps prohibiting us from achieving our aspirations, and, thereby, how we as leaders might intervene to let 'it' support us to act otherwise.

Notwithstanding this, some of the most visible actors in collaborative endeavours are humans and, in particular, those who are appointed to named leadership roles. For Kāhui Ako, these roles include the Community of Learning leader, the Across Schools teacher and the Within School teacher. The Community of Learning leader is charged with responsibility to provide leadership in building productive collaboration, to facilitate the ongoing development and implementation of the achievement plan, to support the professional 
growth of the Kāhui Ako principals and teachers, and to provide leadership in the use of professional expertise across schools to meet the achievement challenges (Ministry of Education, n.d.). Each of these responsibilities would align with insights from the literature; productive collaboration lies not in the appointment of the 'obvious' role such as the principal of a secondary school, or the largest school, or the school with the best results for student achievement. Here, ambiguity models of leadership have much to offer the collaborative agenda. In these models, which were largely developed on the basis of data from educational settings, a number of features are considered: lack of clarity about goals, processes that are not properly understood, loose coupling, uncertainty about 'relative' power, a client-serving focus based on professionalism, fluid participation in decision-making processes, increasing dependence on external groups, unplanned decisions and decentralisation (Bush, 2011). In the face of conditions of ambiguity, two leadership strategies are offered. The first strategy involves a suite of components: a) devote time to decision making; b) persist in the face of proposals that do not gain initial support; c) facilitate the participation of those who oppose proposals; d) overload the system with ideas to ensure success of at least some ideas (Cohen \& March, 1986). Clearly, this strategy is likely to have limited appeal to educators already with a sense of being overburdened with policy initiatives. The second strategy has two components: a) be particularly attentive to the selection and deployment of staff; b) be attentive to structure.

One of the challenges in educational work of the collaborative kind is that those appointed to leadership positions in schools have often not had training in organisational theory in general, and in leading change in particular (Hargreaves, 2011). In their reviews of the evidence thus far, the Education Review Office $(2016,2017)$ underscores the critical role of, particularly, Kāhui Ako leaders. They note that "effective leadership is a defining characteristic" of those communities that have proved effective in making a difference for students (Education Review Office, 2017, p. 17). Leadership has "a crucial role to play" (Education Review Office, 2016, p. 10) in developing vision, negotiating achievement challenges that are meaningful to all stakeholders, and ensuring needed resources are in the right place at the right time. The 2017 review notes that the roles are "complex and dynamic" and "require more than a replication of the knowledge and skill-sets required to lead a school." Their review indicates these roles with their "leadership among leaders" are influencing, rather than authority-based roles that demand evaluative capabilities and the ability to be "nimble" and to maintain a strong focus on "building and sustaining relationship trust at each level of the community." In this, leaders are charged with ensuring organisational design - the structures, processes and practices of Kāhui Ako members - is aligned in ways that strengthen and sustain collaborative activity, rather than strengthening and sustaining individual, competitive activity. While policy is commonly framed around the importance of altruistic values that place ākonga, rather than the institution, at the centre of processes (Higham \& Yeomans, 2010), research in England found this was not the norm; individual schools continued to place institutional concerns at the centre, and conflict was often present (Lumby \& Morrison, 2006), hence, the importance of understanding the dynamics of social capital and putting it to work in incentivised collaborations. 


\section{Social capital as a resource for collaboration}

Social capital refers to "the ways in which social relationships serve as a resource, allowing individuals and groups to cooperate in order to achieve goals that otherwise might have been attained only with difficulty, if at all" (Kilpatrick, Field, \& Falk, 2001, p. 2). The term social capital is frequently connected with Robert Putnam's writing on democracy in modern Italy (Putnam, 1993). Putnam (1995) defines social capital as the:

...norms and networks of civil society that enable groups of individuals to co-operate for the mutual benefit (and perhaps for the broader social benefit) and may allow social institutions to perform more productively. Social capital is embodied in such forms as civic and religious groups, bonds of family, informal community networks, and norms of reciprocity, voluntarism, altruism and trust. (p. 67)

Putnam identified two types of social capital: localised (or private) social capital and generalised (or public) social capital. Generalised social capital grows out of the patterns of reciprocity, collaboration and spirit that are forged in localised forms of social capital. In other words, it is the localised forms of social capital that provide the conditions for public social capital out of which, in turn, a democratic model of the kind aspired to in the fourth way (Hargreaves \& Shirley, 2012) could grow (Putnam 1993a). How does this occur? Firstly, networks foster norms of reciprocity which provide a mechanism to strengthen cooperation in competitive situations. Secondly, networks also facilitate coordination and communication and amplify information about the trustworthiness of other individuals, thereby reducing transaction costs. Finally, networks embody past success at collaboration; they provide a template of how to collaborate in future.

For Coleman (1988), a key aspect is to understand the degree of closure; it is through closure that reciprocity and the prioritising of the 'greater good' is enforced. In a closed network where people know one another, they can combine to constrain group members who do not contribute to the greater good. The consequence of closure is not only important for the norms that can be developed, but also for the trustworthiness of social structures that allow a sense of obligation to grow, all of which are significant in encouraging a 'public good' investment. For Coleman, two forms of social capital - obligations and expectations, and social norms - are facilitated by the role of closure. It is more difficult for a school to defect from an obligation in a structure that has some form of closure given the risk of damage to valued relationships. However, the third form of social capital - information channels - is also facilitated by openness and generativity. Finally, social capital takes the form of "appropriable social organization" (Coleman, 1988, p. 108). Here the key word is 'appropriation': a group initiated for one purpose will be available - will be able to be appropriated - for other purposes. In other words, "organization, once brought into existence for one set of purposes, can also aid others, thus constituting social capital available for use" (Coleman, 1988, p. 108). This is a key consideration for the investment in Kāhui Ako: the social capital built on one achievement challenge will be available for future achievement challenges.

\section{Concluding thoughts}

In this paper, I have introduced the concept of 'wicked problems' and their connection to the turn towards collaboration in educational policy internationally, including in Aotearoa. I have 
looked at evidence, particularly from the United Kingdom, to explore 'what works' and why. I have then explored some theoretical insights into where our focus might need to be in regard to realising the potential of this policy, in the context of a rapidly reforming system of education in Aotearoa.

As a policy direction, I argue that collaboration has much to recommend it. However, it is a complex endeavour and this, particularly in regard to the centrality of relationship and the often "unremarked" (Thrupp, 2018) presence of power tensions within and across collaborations, there are challenges that present negatively (Moore \& Rutherford, 2012). For Moore and Rutherford, the key is to recognise and name these challenges, thereby preventing the collaboration from being side-tracked from its core business. This, in turn, evokes the advice from the beginning of this paper concerning the means to respond to wicked problems. Kāhui Ako participants need to be prepared in ways that enable them to engage in 'transparent political argumentation' not only in regard to the problems of practice with which they are concerned, but with the very policy itself and what its presence, and process, might imply for public education. This is a critical point. Much of the policy rhetoric and provided guidelines speak about structures and processes, and the role of leaders in forming and sustaining relational trust. Yet, Coleman (1994) is one of many theorists who framed an argument that, without risk, the need for trust diminishes. Thus, if the context of education in Aotearoa was other than it is - a competitive, neoliberal endeavour - this reliance on trust would be mediated. Clearly, there is a role for political leadership in fostering this changed context to better support a collaborative policy initiative.

Leadership is also central to our endeavour. Greany, in his review of the development of the self-improving school system in the United Kingdom, suggests that successful system leaders, of the kind we might aspire to see in Kāhui Ako, have one thing in common; they "create the conditions for ... collaboration to happen" (Greany, 2017, p. 63). In part, this involves being aware of the importance of social capital and the need to move beyond "comfortable collaboration" (Chapman \& Hadfield, 2010, p.238), sustainable innovation exhibits the characteristics of a small world (Buchanan, 2002), bonded by strong ties of our 'usual' collaborators, yet sprinkled with the 'weak ties' of more distant community members. These more distant others challenge thinking and enable a collaboration to reach new levels of both engagement - which is essential to policy achievement - and innovation. To close, I suggest a number of key touchpoints that speak to the 'how' of this:

- First, the active and engagement of Boards and their Trustees. This appears self-evident given the accountability role that is held by Boards and their members. Yet active engagement is uncommon. Active engagement not only enriches support for leaders in creating the conditions for success but also equips Trustees, as parents and community members, to build the stores of social capital of the Kāhui Ako.

- Second, know the 'why' of the collaboration. For those Kāhui Ako that have not emerged on the basis of a prior collaboration, this negotiation and articulation of a shared priority mission underpinned by an effective (and ongoing) evaluation of the issues to hand is the essential, and potentially time-consuming, first task. Without it, subsequent actions can quickly become meaningless, and commitment will be lost.

- Third, recognise the role of leaders, wherever they may be, as nodes. Each person closely bonded with the Kāhui Ako needs to engage with the important task of using their social networks to build the active engagement of others, including teachers, students, iwi, industry and so on. 
- Fourth, positional leaders must put structures, processes and people in the service of informal organisational learning and, particularly, the learning that, with trust, can happen at the boundaries between diverse stakeholders.

Finally, theory suggests a focus on process rather than structure. Wicked problems cannot be solved but, rather, demand the application of judgement, over and over again. This embrace of 'over and over again' underscores the need for initiatives such as Kāhui Ako to appreciate the means by which culture is learned (Schein, 1989), and to support participants in a deep understanding of collaboration and the process of change, as well as understanding the change itself, whatever it may be (Fullan, 2015).

\section{References}

Ainscow, M. (2015). Towards self-improving school systems: Lessons from a city challenge. London: Routledge.

Alison, J., \& Aikin, S. (2013). Who should develop initial teacher education policy and why? Waikato Journal of Education, 18(1), 135-145. https://doi.org/10.15663/wje.v18i1.148

Baars, S., Bernardes, E., Elwick, A., Malortie, A., McAleavy, T., Mclnerney, L., . . Riggal, A. (2014). Lessons from London schools: Investigating the success. London: CrBT Education Trust. Retrieved from https://www.educationdevelopmenttrust.com/ EducationDevelopmentTrust/files/60/60f327fd-cfbc-4d26-b914-0d0ccf84fd78.pdf

Balloch, S., \& Taylor, M. (Eds.). (2001). Partnership working: Policy and practice. Bristol: Policy Press.

Buchanan, M. (2002). Small world: Uncovering nature's hidden networks. London: Weidenfeld Nicolson.

Bush, T. (2011). Theories of educational leadership \& management ( $4^{\text {th }}$ ed.). London: Sage.

Catron, B. L. (1981). On taming wicked problems. Dialogue, 3(3), 13-16.

Chapman, C., \& Hadfield, M. (2010). Supporting the middle tier to engage with school-based networks: Change strategies for influencing and cohering. Journal of Educational Change, 11(3), 221-240. https://doi.org/10.1007/s10833-009-9125-y

Charteris, J., \& Smardon, D. (2018). Policy enactment and leader agency: The discursive shaping of political change. New Zealand Journal of Teachers' Work, 15(1), 28-45. https://doi.org/10.24135/teacherswork.v15i1.237

Churchman, C. W. (1967). Wicked problems. Management Science, 14(4), B141-142.

Cohen, M., \& March, J. G. (1986). Leadership and ambiguity: The American college president. Boston, MA: Harvard Business School Press.

Coleman, J. (1988). Social capital in the creation of human capital. American Journal of Sociology, 94, Supplement S95-120.

Coleman, J. (1994). Foundations of social theory. Cambridge, MA: Harvard University Press.

Crowley, K., \& Head, B. (2017). The enduring challenge of 'wicked problems': Revisiting Rittel and Webber. Policy Sciences, 50(4), 539-547. https://doi.org/10.1007/s11077-0179302-4

Datnow, A. (2005). The sustainability of comprehensive school reform models in changing district and state contexts. Educational Administration Quarterly, 41(1), 121-153. https://doi.org/10.1177/0013161X04269578 
Denters, B., \& Rose, L. (2005). Comparing local governance: Trends and developments. Basingstoke: Palgrave.

Eacott, S. (2015). Educational leadership relationally: A theory and methodology for educational leadership, management and administration. Rotterdam: Sense.

Education Review Office. (2016). Collaboration to improve learner outcomes. What does the evidence tell us about what works. Wellington: New Zealand Government.

Education Review Office. (2017). Communities of learning / Kāhui Ako in action. What we know so far. Wellington: Author. Retrieved from https://www.ero.govt.nz/assets/ Uploads/Communities-of-Learning-Kahui-Ako-Action.pdf https:doi.org/ISBN 978-0-478-43853-6

Elliott, J. (1996). Quality assurance, the educational standards debate, and the commodification of educational research. Paper presented at the British Educational Research Association, Lancaster.

Fullan, M. (2015). The new meaning of educational change ( $5^{\text {th }}$ ed.). New York: Teachers College Press.

Geddes, M. (2003). Limits to local governance: Recent experience in the United Kingdom. Paper presented at the Partnerships, Community and Local Governance: International Perspectives and Australian Experiences, Melbourne.

Giddens, A. (1998). The third way: The renewal of social democracy. Cambridge: Polity Press.

Giddens, A. (2002). Runaway world: How globalisation is reshaping our lives. London: Profile.

Greany, T. (2017). Collaboration, partnerships and system leadership across schools. In P. Earley \& T. Greany (Eds.), School leadership and education system reform (pp. 5665). London: Bloomsbury Academic.

Hargreaves, A. (2011). Leading a self-improving school system. Nottingham: NCSL.

Hargreaves, A., \& Shirley, D. (2012). The fourth way. In M. Preedy, N. Bennett, \& C. Waise (Eds.), Educational leadership: Context, strategy and collaboration (pp. 283-289). London: Sage.

Higham, J., \& Yeomans, D. (2010). Working together? Partnership approaches to 14-19 education in England. British Educational Research Journal, 36(3), 379-401.

Jessop, B. (1998). The rise of governance and the risks of failure: The case of economic development. International Social Science Journal, 155, 28-43.

Kamp, A. (2006). A study of the Geelong Local Learning and Employment Network (PhD Thesis). Faculty of Education, Deakin University, Geelong, Australia.

Kamp, A. (2013). Rethinking learning networks: Collaborative possibilities for a Deleuzian century. Oxford: Peter Lang.

Kamp, A. (2017). Assembling the actors: Exploring the challenges of 'system leadership' in education through Actor-Network Theory. Journal of Education Policy, 33(6), 778792. https://doi.org/10.1080/02680939.2017.1380231

Kamp, A. (2019). Actor-Network Theory. Retrieved from https://oxfordre.com/education/view/10.1093/acrefore/9780190264093.001.0001/ acrefore-9780190264093-e-526

Kearney, A., Mentis, M., \& Holley-Boen, W. (2017). Informal, non-formal, and formal networking: Ensuring autonomy and flexibility for special needs coordinators. New Zealand Journal of Teachers' Work, 14(2), 114-135. https://doi.org/10.24135/teacherswork.v14i2.234 
Kickert, W. J. M., Klijn, E. H., \& Koppenjan, J. F. M. (Eds.). (1997). Managing complex networks. Strategies for the public sector. London: Sage.

Kidron, Y., \& Darwin, M. J. (2007). A systematic review of whole school improvement models. Journal of Education for Students Placed at Risk, 12(1), 9-35. https://doi.org/10.1080/10824660701247226

Kilpatrick, S., Field, J., \& Falk, I. (2001). Social capital: An analytical tool for exploring lifelong learning and community development [Discussion Paper]. Launceston, Tasmania: Centre for Research and Learning in Regional Australia, University of Tasmania, Australia.

Kirby, P. (2000). Ministerial review of post compulsory education and training pathways in Victoria [Ministerial Report]. Melbourne: Department of Education, Employment and Training.

Kirkpatrick, I., Ackroyd, S., \& Walker, R. M. (2005). The new managerialism and public sector professionals. London: Palgrave.

Kjaer, I. (2003). Local partnerships in Europe: An action research project. Copenhagen: Copenhagen Centre.

Latour, B. (2004). Why has critique run out of steam? From matters of fact to matters of concern. Critical Inquiry, 30(2), 225-248.

Law, J. (2009). Actor network theory and material semiotics. In B. S. Turner (Ed.), The New Blackwell companion to social theory (pp. 141-158). Chichester: Wiley-Blackwell.

Lumby, J., \& Morrison, M. (2006). Partnership, conflict and gaming [Article]. Retrieved from doi.10.1080/02680930600600564

McCarthy, H., Miller, P., \& Skidmore, P. (2004). Network logic: Who governs in an interconnected world? London: DEMOS.

Ministry of Education. (2016). Communities of Learning guide for schools and kura.

Wellington: Author. Retrieved from

https://www.education.govt.nz/assets/Documents/col/Communities-of-LearningGuide-for-Schools-and-Kura-web-enabled.pdf

Ministry of Education. (2017). Uptake and early implementation: Communities of learning I Kāhui Ako. Wellington: Author. Retrieved from https://www.educationcounts.govt.nz/publications/schooling/181545

Ministry of Education. (2018). Communities of learning: Kāhui Ako 2017 survey. Wellington: Author.

Ministry of Education. (2019). Supporting all schools to succeed: Reform of the Tomorrow's Schools system. Wellington: Author.

Ministry of Education. (n.d.). Community of Learning leader. Retrieved from https://www.education.govt.nz/communities-of-learning/leadership-andgovernance/community-of-learning-leader/

Moore, T. A., \& Rutherford, D. (2012). Primary strategy learning networks: A local study of a national initiative. Educational Management Administration \& Leadership, 40, 6983.

Nuttall, J. (2012). Challenges, opportunities, and capacity building in early childhood teacher education research in Australia and New Zealand. New Zealand Journal of Educational Studies, 47(1), 65-78.

O'Flynn, J. (2007). From new public management to public value: Paradigmatic change and managerial implications. The Australian Journal of Public Administration, 66(3), 353366. 
OECD. (2015). Education policy outlook: Making reforms happen. Paris: Author. Retrieved from http://dx.doi.org/10.1787/9789264225442-en

Putnam, R. D. (1993, March). The prosperous community: Social capital and public life. The American Prospect, 4(13), 1-6.

Putnam, R. D. (1995). Bowling alone: America's declining social capital. Journal of Democracy, 6(1), 65-78.

Ramsey, P., \& Poskitt, J. (2019). Understanding leadership dynamics 'Within' and 'Across School' roles - and moving forward. New Zealand Principals' Federation Magazine, 34(1), 10-12.

Rith, C., \& Dubberly, H. (2007). Why Horst W. J. Rittel matters. Design Issues, 23(1), 72-74.

Schein, E. H. (1989). Organizational culture: What it is and how to change it. In P. Evans, Y. Doz, \& A. Laurent (Eds.), Human resource management in international firms (pp. 56-82). Basingstoke: Macmillan.

Tett, L. (2005). Partnerships, community groups and social inclusion. Studies in Continuing Education, 27(1), 1-15.

Thrupp, M. (2018). To be 'in the tent' or abandon it? A school clusters policy and the responses of New Zealand educational leaders. In J. Wilkinson, R. Niesche, \& S. Eacott (Eds.), Challenges for public education: Reconceptualising educational leadership, policy and social justice as resources for hope (pp. 132-144). Abingdon, UK: Routledge.

Wenger, E. (2000). Communities of practice and social learning systems. Organizational Articles, 7(2), 225-246.

Wylie, C. (2012). Vital connections: Why we need more than self-managing schools. Wellington, New Zealand: NZCER Press.

\section{Biographical Note}

Associate Professor Annelies Kamp is Head of School of Educational Studies and Leadership and Deputy Pro-Vice Chancellor for the College of Education, Health and Human Development at the University of Canterbury. Her research interests focus on system leadership, critical youth studies, contemporary theory and new materialism. Her two most recent books are Re/Assembling the Pregnant and Parenting Teenager (Peter Lang, 2017, available fully open source) and Education Studies in Aotearoa: Key Disciplines and Emerging Directions (NZCER, 2019).

Email: annelies.kamp@canterbury.ac.nz

ORCID: 0000-0002-9442-0908 